Altai State University

Acta 3iologica Gibirica

Journal of Biology

\title{
Morphometric study of hybridogenic species in Veronica subgenus Pseudolysimachium (Plantaginaceae)
}

\author{
P. Kosachev ${ }^{1}$, V. Novikova ${ }^{1}$, S. Pfanzelt ${ }^{2}$, S. Schöngart ${ }^{2}$, D. Albach ${ }^{2}$ \\ 1Altai State University, Lenina 61, Barnaul, 656049, Russia, E-mail: pakosachev@yandex.ru \\ 2 Carl von Ossietzky-University Oldenburg, Carl von Ossietzky-Str. 9-11, Oldenburg, 26111, Germany
}

We demonstrate the results of morphometric investigations of hybrids in Veronica subg. Pseudolysimachium $(V . \times$ altaica Kosachev und $V$. $\times$ kolyvanensis Kosachev et Shmakov) and their parents. Based on PCoA analysis with seven morphological characters, we reveal an intermediate position of the investigated hybrids and the most important taxonomic characters: ratio of length and width of the lamina of the upper leaves, height of plants, length of the longest corolla lobe and calyx lobe, presence of hairs on the calyx and their position, as well as the length of hairs on the internode below the inflorescence.

Key words: PCOA analysis, hybridization, Veronica spicata and related species, Veronica $\times$ altaica, Veronica $\times$ kolyvanensis, Altai Mountains, southeastern Europa

\section{Introduction}

Härle (1932) suggested that hybridization played an important role in the diversification of the subgenus (formerly variously classified as section or separate genus) and groups of morphological races („Formenkreise“) are connected by transitional forms. Later authors (Fischer, 1974; Trávniček, 1998; Albach, Fischer, 2003; Trávniček et al. 2004) partly disagreed and stressed species boundaries, especially based on different types of indumentum (especially presence of glandular hairs). Recent molecular results partly support these species but also emphasized the many transitional forms (Bardy et al., 2011).

Within $V$. subg. Pseudolysimachium a number of hybrids have been proposed involving $V$. spicata and its relatives (Härle, 1932; Fischer, 1974; Klokov, 1976; Tsvelev, 1981; Kosachev, 2003, Kosachev, German, 2004; Kosachev, Ebel, 2010; Bardy et al., 2011; Kosachev et al., 2013, 2016, 2017). In the Altai Flora six hybrids are known: V. × altaica Kosachev (V. spicata $\times$ V. pinnata), V. $\times$ czemalensis Kosachev et Albach $(V$. porphyriana $\times V$. incana), V. $\times$ grisea Kosachev et A.L. Ebel $(V$. incana $\times$ V. longifolia), $V . \times$ kolyvanensis Kosachev et Shmakov $(V$. spicata $\times$ V. spuria), V. $\times$ schmakoii Kosachev $(V$. porphyriana $\times V$. longifolia), $V$. $\times$ sessiliflora Bunge $(V$. porphyriana $\times V$. pinnata).

Kosachev et al. (2016) demonstrated using comparison of DNA sequence data that some of these hybrids indeed involve the proposed parents but for others the complexity of gene flow and introgression between putative parental species and spatial differentiation within these species makes diagnosis of hybrids using molecular tools alone difficult. Therefore, multidimensional comparative investigatioins using several modern methods and data analysis are required to elucidate patterns of ancestry in the putative hybrids.

One of these approaches was followed in an international project to investigate patterns of adaptive introgression in Veronica spicata and relatives involving scientists from three countries: Germany, Ukraine and Russia. The project combines various methods such as molecular genetics (high-throughput sequencing), flow cytometry, ultrastructural analysis of seed and pollen and morphometrics. In the present contribution we present the results of the morphometric analysis of $V$. spicata and two of its hybrids in the Altai region with the aim to test the hypothesis of hybridization using morphometric analysis and the potential for introgression between parent species via these hybrids.

\section{Materials and Methods}

For the investigation of Veronica subg. Pseudolysimachium we used herbarium specimens of recent expeditions $(2016,2017)$ to the Altai and Europe (Table 1). Voucher specimens are stored in the herbaria ALTB, KW, and OLD. 
Kosachev, P. et al. Morphometric study of hybridogenic species in Veronica .... Acta Biologica Sibirica, 2018, 4(2), 47-52

Table 1. Investigated taxa, voucher number and locality

\begin{tabular}{|c|c|c|}
\hline Species & Voucher number (ALTB) & Locality \\
\hline \multirow[t]{6}{*}{ V. pinnata } & $\operatorname{pin} 1189$ & $\begin{array}{l}\text { Russia, Altai Republic, Ongudayskii distr., Aygulak River mouth, h = } \\
\text { 1074, 22.07.2016; N 50.35958, E 87.24648 }\end{array}$ \\
\hline & pin1166 & $\begin{array}{l}\text { Russia, Altai Republic, Ulaganskii distr., Chuisky Trakt, Chuya River, c. } \\
15 \text { km W of Aktash, N 50,35007, E 87,41245 }\end{array}$ \\
\hline & $\operatorname{pin} 1162$ & $\begin{array}{l}\text { Russia, Ongudayskii distr., B. Ilgumen River, h = } 982 \text { m, 16.07.2016; } \\
\text { N 50.64244, E 86.36352 }\end{array}$ \\
\hline & pin1139 & $\begin{array}{l}\text { Russia, Altaiskii krai, Tretjakovskii distr., above Aley River, h = } 394 \text { m, } \\
\text { 13.07.2016; N 50.91591, E 82.32704 }\end{array}$ \\
\hline & Vouch21 & $\begin{array}{l}\text { Russia, Republic Altai, Ulaganskii distr., } 8 \text { km SSE from village Aktash, } \\
\text { River valley, H = 1491,5 m, steppe, N 50.344583, E } 87.441745\end{array}$ \\
\hline & Vouch5_1 & $\begin{array}{l}\text { Russia, Republic Altai, Ulaganskii distr., Chulyshman River, } \mathrm{H}=627,8 \\
\text { m, steppe, N } 50^{\circ} 58^{\prime} 39^{\prime \prime}, \text { E } 88^{\circ} 05^{\prime} 24,8^{\prime \prime}\end{array}$ \\
\hline \multirow[t]{2}{*}{ V. $\times$ altaica } & alt1140, alt1, alt2, alt4 & $\begin{array}{l}\text { Russia, Altaiskii krai, Tretjakovskii distr., above Aley River, h=394 m, } \\
\text { 13.07.2016; N 50.91591, E 82.32704 }\end{array}$ \\
\hline & alt3 & $\begin{array}{l}\text { Russia, Altaiskii krai, Tretjakovskii distr., mount Poruczikova, village } \\
\text { Ekaterininskoe, N 5054'30.8", E } 82^{\circ} 00^{\prime} 56.6 \text { "E }\end{array}$ \\
\hline \multirow[t]{12}{*}{ V. spicata } & spic1127 & $\begin{array}{l}\text { Russia, Altaiskii krai, Kurjinskii distr., } 15 \text { km N of Kurja, h=213 m, } \\
\text { 12.07.2016; N 51.76835, E 82.13831 }\end{array}$ \\
\hline & spic1141, 1144 & $\begin{array}{l}\text { Russia, Altaiskii krai, Kurjinskii distr., Loktewka River, h = } 423 \text { m, } \\
\text { 14.07.2016; 51.29644 N, 82.49078 E }\end{array}$ \\
\hline & spic1138 & $\begin{array}{l}\text { Russia, Altaiskii krai, Tretjakovskii distr., above Aley River, } h=394 \text { m, } \\
\text { 13.07.2016; N 50.91591, E 82.32704 }\end{array}$ \\
\hline & spic1135 & $\begin{array}{l}\text { Russia, Altaiskii krai, Zmeinogorskii distr., } 3 \text { km N of Lake } \\
\text { Kolyvanskoye, N 51.39235, E 82.20837 }\end{array}$ \\
\hline & spic5U & $\begin{array}{l}\text { Ukraine, Oblast Kiew: Koccha zaspa meadows, grassland, } 19.5 \text { m } \\
\text { from creek margin, h = } 92 \text { m; N 50.329417 E } 30.578733\end{array}$ \\
\hline & spic12U & $\begin{array}{l}\text { Ukraine, Oblast Chmelnyzkyj: Four-Horseman, near Verbka, } \\
\text { meadows, low grass, h = } 252 \text { m; N 48.801483, E } 26.598317\end{array}$ \\
\hline & spic14U & $\begin{array}{l}\text { Ukraine, Oblast Tscherniwzi: between Shershenivka and Oleksyntsi, } \\
\text { meadows, grass, rocks, h = } 206 \text { m; N 48.817200, E } 25.829733\end{array}$ \\
\hline & spic1H & $\begin{array}{l}\text { Hungary, Tar-Kö, Bükk NP, cliffs, h = } 950 \text { m; N 4802'21.72", E } \\
20^{\circ} 27^{\prime} 39.96^{\prime \prime}\end{array}$ \\
\hline & spic2H & $\begin{array}{l}\text { Hungary, Borsod-Abauj-Zemplen: Pereces, tall grass meadow above } \\
\text { orchard, h = } 250 \mathrm{~m} \text {; N 48 } 07^{\prime} 49.96^{\prime \prime}, \text { E } 20^{\circ} 40^{\prime} 54.50^{\prime \prime}\end{array}$ \\
\hline & spic19H & $\begin{array}{l}\text { Hungary, Eisenburg: Sarvar, } 47^{\circ} 17^{\prime} 02.76^{\prime \prime} \mathrm{N} 17^{\circ} 02^{\prime} 22.62^{\prime \prime} \mathrm{E}, \\
\text { abandoned vineyard, on basalt, } \mathrm{h}=186 \mathrm{~m} ; \mathrm{N} 47^{\circ} 17^{\prime} 02.76^{\prime}, \mathrm{E} \\
17^{\circ} 02^{\prime} 22.62^{\prime \prime}\end{array}$ \\
\hline & spic21H & $\begin{array}{l}\text { Hungary, Sar-Hegy, Gyöngyös, open vineyard, h = } 280 \text { m; N } \\
47^{\circ} 48^{\prime} 20.74^{\prime \prime}, \text { E 1959’30.96" }\end{array}$ \\
\hline & spic25H & $\begin{array}{l}\text { Hungary, Eisenburg: Tokorcs, dry meadow, h=190 m; N } \\
47^{\circ} 17^{\prime} 37.98^{\prime \prime}, \mathrm{E} 17^{\circ} 06^{\prime} 15.24^{\prime \prime}\end{array}$ \\
\hline \multirow[t]{2}{*}{ V. $\times$ kolyvanensis } & kol1143, kol1143_2 & $\begin{array}{l}\text { Russia, Altaiskii krai, Kur'inskii distr., Loktewka River, h = } 423 \text { m, } \\
\text { 14.07.2016; N 51.29644, E 82.49078 }\end{array}$ \\
\hline & $\begin{array}{l}\text { kol1128, kol1128_2, } \\
\text { kol1128_3 }\end{array}$ & $\begin{array}{l}\text { Russia, Altaiskii krai, Kur'inskii distr., along roadside (K9) between } \\
\text { Pospelikha and Kurya (c. } 20 \text { km NNW of Kurya), N 51.76835, E } \\
82,13832\end{array}$ \\
\hline V. spuria & $\begin{array}{l}\text { spur1142, spur1142_2, } \\
\text { spur1142_3 } \\
\text { spur1126, spur1126_1 }\end{array}$ & $\begin{array}{l}\text { Russia, Altaiskii krai, Kur'inskii distr., Loktewka River, h = } 423 \text { m, } \\
\text { 14.07.2016; N 51.29644, E } 82.49078 \\
\text { Russia, Altaiskii krai, Kur'inskii distr., along roadside (K9) between } \\
\text { Pospelikha and Kurya (c. } 20 \text { km NNW of Kurya) N 51.76835, E } \\
82,13832\end{array}$ \\
\hline
\end{tabular}

Here, we investigated two hybridogenic taxa $V . \times$ altaica with its parents $V$. spicata and V. pinnata; V. $\times$ kolyvanensis with its parents $V$. spicata and $V$. spuria. For the study we used 33 herbarium specimens from 24 populations. For all taxa, at least 10 plants were scored and all characters measured at least five times. All measurements were conducted under a light microscope Olympus BX 51 with the software ZEN (Carl Zeiss).

Quantitative measurements were conducted on the basis of the study by Bardy et al. (2011). The authors of this study initially investigated 18 potentially informative morphological characters (1 qualitative, 17 quantitative characters) 
based on suggestions by Albach \& Fischer (2003). Nine of these characters were shown to be correlated and excluded by Bardy et al. (2011).

In our study we used the following important, diagnostic characters (Table 2): Two characters - percentage of stalked glandular hairs on sepals and percentage of sessile glandular hairs on sepals - were not used due to large error in measurements. However, we have adapted these characters to a further qualitative character, the presence of glandular hairs on sepals. If present, we have also noted the distribution (ciliate vs. Present also on the surface).

The data matrix was converted in a distance matrix using the Gower-coefficient for a PCoA. All analyses were conducted using R v. 2.10 .1 (https://cran-archive.r-project.org/bin/windows/base/old/2.10.1/).

Table 2: Morphological characters used in the analysis with their abbreviation

\begin{tabular}{ll}
\hline Abbreviation & Morphological character \\
LLP & Length of the longest petal \\
WC & Width of corolla \\
LLS & Length of the longest sepal \\
LWL & Length / width of lamina of the leaf pair below the one subtending the inflorescence \\
PH & Total plant height \\
SHL & Length of hairs on stem on the internodium below the inflorescence \\
& Absence (1) or presence (2 / 3) of hairs on the calyx. If present, hairs were score: (2) simple 3- \\
GH & 4-celled hairs on the margin and 1-2-celled glandular hairs on the surface; (3) only 1-2-celled \\
\hline
\end{tabular}

\section{Results}

The analysis of principal coordinates demonstrate almost complete separation of the taxa using our seven characters. Figure 1 depicts the situation for $V . \times$ altaica and its putative parents.

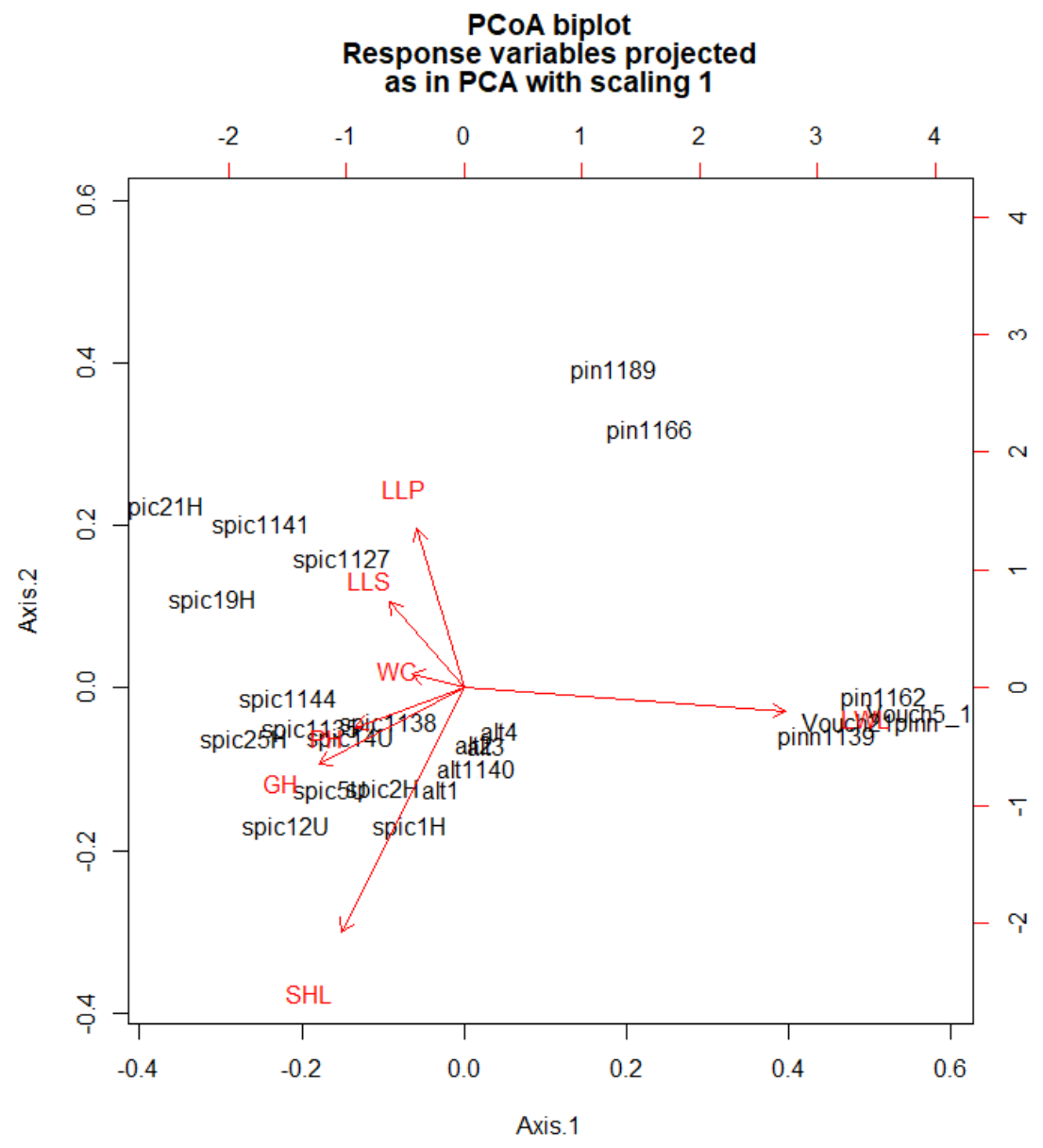

Fig. 1. Principal Co-ordinate Analysis of a matrix of pair-wise Gower distances based on 7 morphological characters scored for 24 individuals from 20 populations of the Veronica $\times$ altaica and its putative parents $V$. spicata and $V$. pinnata from weastern Altai Mountains and southeastern Europa 
Veronica pinnata is clearly separated from all other taxa along axis 1 on the basis of ratio length to width of lamina. Additionally, populations pin1189 and pin1166, growing close to each other in the Chuya valley, are separated from other populations of the species due to differences in corolla size.

$V$. $\times$ altaica is separated from the putative parent $V$. pinnata by all characters but not from its other putative parent, $V$. spicata. However, mixture occurs only through the Hungarian population spic1 $\mathrm{H}$ through the character hair length on the internode below the inflorescence. Veronica $\times$ altaica differs from all other populations, including the sympatric ones, in this character.

$V$. spicata is diverse in our measured characters and no differentiation between populations, e.g. between European and Asian populations is discernable. Least variation is detected in width of the corolla and length of longest sepal.

Figure 2 depicts the PCoA for $V$. $\times$ kolyvanensis.

All three taxa are markedly differentiated from each other. On axis $1, V$. spuria is separated markedly from the other taxa by the character height of plants. For $V . \times$ kolyvanensis height of plants and length of longest corolla lobe are positively correlated. Population spic1127, which is sympatric with kol1128 in Kur'inskii region of the Altaiiskii krai, is closest to $V$. $\times$ kolyvanensis, especially due to length of longest corolla lobe but also all other characters. Noteworthy is some separation between Asian and European populations of $V$. spicata using characters SHL, WC and GH (hair length on stem, corolla width, calyx indumentum).

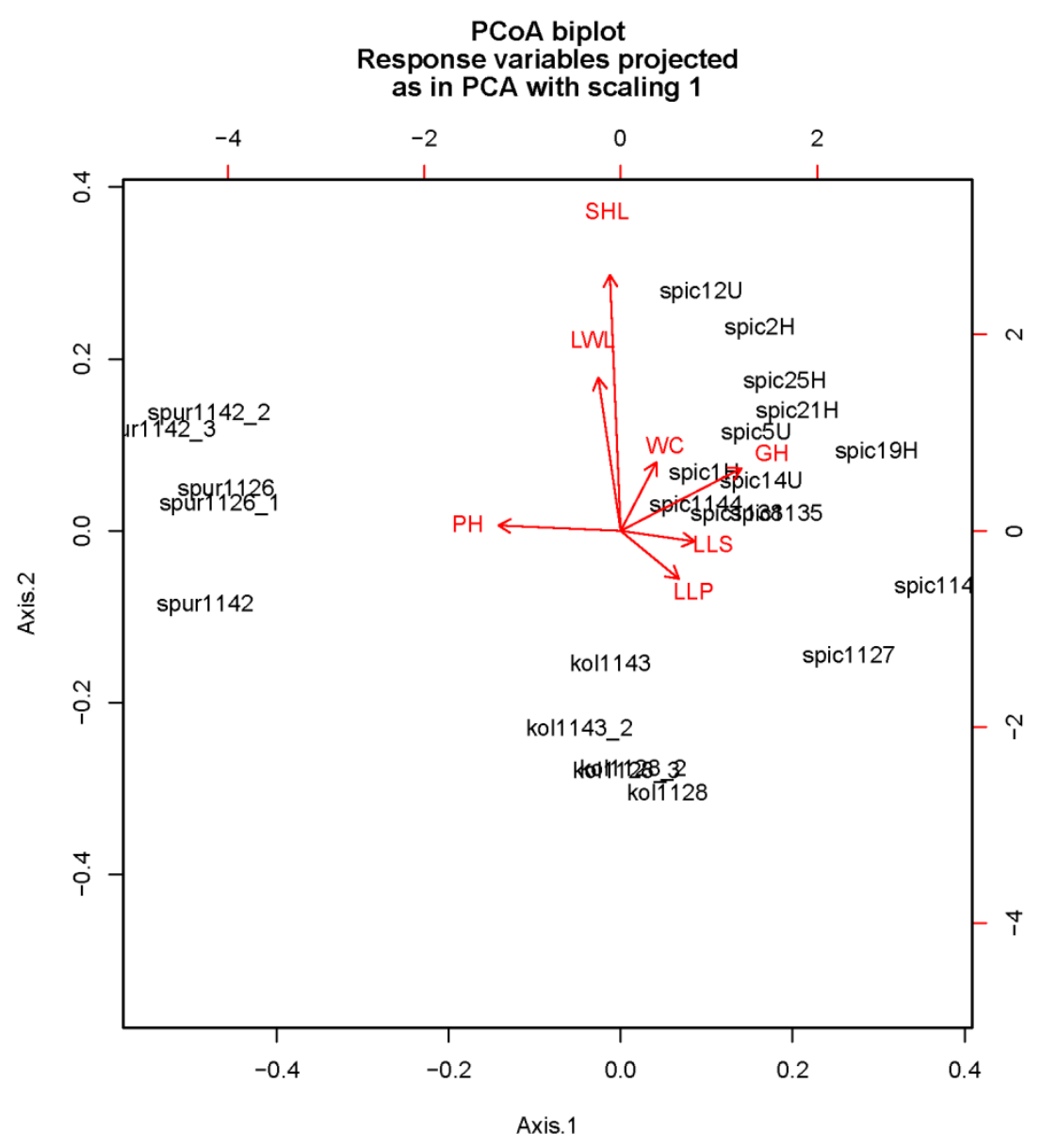

Fig. 2. Principal Co-ordinate Analysis of a matrix of pair-wise Gower distances based on 7 morphological characters scored for 25 individuals from 16 populations of the Veronica $\times$ kolyvanensis and its putative parents $V$. spicata and $V$. spuria from weastern Altai Mountains and southeastern Europa

\section{Discussion}

In both cases can we recognize a clear separation of the taxa. This may partly due to putative parents being in different subsections of $V$. subg. Pseudolysimachium with clear morphological distinction. Another part of the explanation is that we chose examples with hybrids markedly differing from its parents to prove that our approach works in cases of a priori distinct hybrids.

In both cases, hybrid taxa take on an intermediate position between the parents. Special importance in this respect have characters such as ratio of length and width of leaf lamina $(V . \times$ altaica $)$ and height of plants $(V . \times$ kolyvanensis).

Populations of $V$. pinnata are well characterized by the ratio of length to width of the lamina in upper leaves. Leaves are linear and much longer than wide. In general, the species is easily distinguished by the pinnatifid leaves with linear segments and set apart in Sect. Pinnatae (Holub) Kosachev et Albach (Subg. Pseudolysimachium). Populations from the Chuva valley (pin1189, pin1166) are distinguished from other populations by longer corolla lobes, approaching $V$. spicata 
and $V$. porphyriana. It is possible that introgressive hybridization with $V$. porphyriana, which is only sympatric with $V$. pinnata in the Western Altai, plays a role. Here, the hybrid of both species, $V . \times$ sessiliflora, has been described.

Populations of $V . \times$ altaica resemble $V$. spicata in ratio of leaf length to width, presence of glandular hairs on the sepals and height of plants. Preliminary analyses of NGS data suggest that $V$. $\times$ altaica serves mainly as a way of introgression towards $V$. spicata (Felgentreu \& Albach, unpubl.). However, alternative scenarios will need to be investigated based on differences between $V$. $\times$ altaica and both its parents. For example, $V$. $\times$ altaica and $V$. spicata differ in the Altai in length of hairs on stem below inflorescence with $V . \times$ altaica having $1.5-2 \times$ longer hairs than $V$. spicata. It is not clear whether this character is transgressive or hints at hybridization with a third species. A sample of $V$. spicata from Hungary, which we identified as $V$. spicata ssp. fischeri, has been noted to have even longer hairs, $2 \times$ longer than $V . \times$ altaica and 3-4x longer hairs than $V$. spicata in the Altai. Whether this is due to mutations in this subspecies or due to introgression from yet another taxon (e.g., $V$. incana) will also need to be further investigated. Bardy et al. (2011) provided some evidence for the latter. If a transgressive elongation of hairs in hybrids is possible in $V$. $\times$ altaica, it may, however, also be possible in $V$. spicata ssp. fischeri without introgression from $V$. incana. Since apart from hair length, corolla width and calyx indumentum differ between populations of $V$. spicata in Europe and the Altai, and we also see this in DNA sequence analysis (Felgentreu \& Albach, unpubl.), the differentiation in V. spicata will definitely need further analysis.

$V$. $\times$ kolyvanensis is intermediate between its putative parents $V$. spicata and $V$. spuria in height of plants and length of longest corolla lobe. Specimens of $V$. spicata sympatric with $V . \times$ kolyvanensis samples (spic1127, spic1141) approach $V$. $\times$ kolyvanensis, again suggesting possible introgression. Other characters demonstrate a mixture in $V$. $\times$ kolyvanensis, such as indumentum on the sepals, which comprises short glandular hairs on the surface, resembling $V$. spicata, and also the margin, where $V$. spicata has long cilia but similar to V. spuria, which in turn has glabrous sepal surface. The latter species is clearly distinct from the other studied species based on height of plants, glabrous sepal surface and short corolla and calyx lobes.

Finally, we found decisive differences between European V. spicata and specimens from the Altai in length of hairs on stem on the internodium below the inflorescence and on the sepals. Future genetic analyses, therefore should consider introgression between $V$. incana and V. spicata in Europe.

In summary, we have demonstrated that hybrids in $V$. subg. Pseudolysimachium are distinguishable from its parents using morphological analysis. The most important characters in this respect are ratio of leaf length to leaf width, height of plants, length of hairs, as well as its distribution on its calyx. Furthermore, morphometrics is also able to provide initial hypotheses for introgression between species and their hybrids. These hypotheses will need to be further analyzed using comparative morphological and molecular analyses.

\section{Acknowledgments}

The study was supported by the Volkswagen-Foundation, project 90256.

\section{References}

Albach, D.C., Fischer, M.A. (2003). AFLP- and genome size analyses: contribution to the taxonomy of Veronica subg. Pseudolusimachium sect. Pseudolysimachion (Plantaginaceae), with a key to the European taxa. Phytologia Balcan., 9. 401424.

Bardy, K.E. (2011). Extensive gene flow blurs species boundaries among Veronica barrelieri, V. orchidea and V. spicata (Plantaginaceae) in southeastern Europe. Taxon. 60(1). 108-121.

Fischer, M. (1974). Beitrag zu einer systematischen Neubearbeitung der Gruppe um Pseudolysimachion spicatum (L.) Opiz (= Veronica spicata L.). Phyton. 16(1-4). 29-47.

Härle, A. (1932). Die Arten und Formen der Veronica-Sektion Pseudolysimachia Koch auf Grund systematischer und experimenteller Untersuchungen. Bibliotheca Botanica. 26. 1-86.

Klokov, M.V. (1976). About Veronica spicata group // Novit. Syst. PI. non Vasc. and Vasc. (1975). 92-111 [in Russian].

Kosachev, P.A. (2003). Review of the section Pseudolysimachium W. D. J. Koch (Genus Veronica L., Scrophulariaceae) in Altai Mountains. Turczaninowia. 6(1). 11-33 [in Russian].

Kosachev, P.A., Albach, D.C., Ebel, A.L. (2015). Check-list of Veronica subg. Pseudolysimachium (Plantaginaceae) of Siberia. Turczaninowia. 18(3). 84-95.

Kosachev, P.A., Albach, D., Shaulo, D.N., Shmakov, A.I. (2013). New species of Veronica subgen. Pseudolysimachium (Plantaginaceae Juss.). Turczaninowia. 16(3). 8-14 [in Russian].

Kosachev, P., Behçet, L., Mayland-Quellhorst, E., Albach, D.C. (2016). Analyzing Reticulate Relationships Using CpDNA and Pyrosequenced ITS1 as Exemplified by Veronica subgen. Pseudolysimachium (Plantaginaceae). Syst. Botany. 41(1). 105119.

Kosachev, P.A., Ebel, A.L. (2010). Notes on Veronica L. in Siberia. Animadversiones Systematicae ex Herbario Kryloviano Universitatis Tomskensis. 102. 3-11 [in Russian].

Kosachev, P.A., German, D.A. (2004). New species of genus Veronica L. (Scrophulariaceae) from the Western Mongolia. Novit. Syst. Vasc. PI. 36. 209-212 [in Russian]. 
Kosachev, P., Pfanzelt, S., Mayland-Quellhorst, E., Albach, D. (2017). The distribution of endemic species Veronica $\times$ czemalensis Altai according to the analysis of NGS (Next Generation Sequencing). Proceedings of the 16th International Scientific and Practical Conference (Barnaul, 5-8 June 2017). 250-253 [in Russian].

Trávniček, B. (1998). Notes on the taxonomy of Pseudolysimachion sect. Pseudolysimachion (Scrophulariaceae) in Europe. I. P. incanum and P. spicatum. Preslia. 70. 193-223.

Trávniček, B., Lysák, M.A., Číhalíkova, J. \& Doležel, J. (2004). Karyo-taxonomic study of the genus Pseudolysimachion (Scrophulariaceae) in the Czech Republic and Slovakia. Folia Geobot., 39. 173-203.

Tsvelev, N.N. (1981). Veronica L. iz rodstva V. spicata L. i nekotorye voprosy filogenii etogo roda. Bulletin of Moscow Society of Naturalists, 86(6). 82-92 [in Russian].

\section{Citation:}

Kosachev, P., Novikova, V., Pfanzelt, S., Schöngart, S., Albach, D. (2018). Morphometric study of hybridogenic species in Veronica subgenus Pseudolysimachium (Plantaginaceae). Acta Biologica Sibirica, 4 (2), 47-52.

Submitted: 13.02.2018. Accepted: 25.04.2018

cross ref http://dx.doi.org/10.14258/abs.v4i2.4123

(C) 2018 by the authors. Submitted for possible open access publication under the terms and conditions of the Creative Commons Attribution (CC BY) license (http://creativecommons.org/licenses/by/4.0/). 